Гріненко О. І., к. військ.н.;

Кутовий О. П., к.т.н., с.н.с.;

Шапталенко М. І., к.т.н., доцент

Центр воєнно-стратегічних досліджень Національного університету оборони України імені Івана Черняховського, Київ

\title{
Сучасні проблеми мобілізаційної підготовки і мобілізації оборонного сектору національної економіки та шляхи їх розв'язання
}

Резюме. У статті обгрунтовано необхідність удосконалення системи управління та організації планування мобілізаційної підготовки підприємств, установ і закладів оборонного сектору національної економіки певними способами для задоволення потреб збройних сил. Запропоновано необхідний апарат для розв'язання визначених проблем.

Ключові слова: озброєння; військова техніка; мобілізаційна підготовка та мобілізація; мобілізаційні спроможності; оборонний сектор національної економіки.

Постановка проблеми. В умовах глобальних політичних перетворень у світі, появою нових рис сучасних воєнних конфліктів, радикальних змін в економіці держави $\mathrm{i}$ Збройних Силах України (ЗС України) вкрай актуальним стає питання задоволення потреб військ (сил) озброєнням, військовою технікою (OBT), іншими матеріально-технічними засобами (Мт3). Досвід останніх років засвідчив неспроможність підприємств Укроборонпрому, інших галузей економіки забезпечити потреби військових формувань в ОВТ певної номенклатури, іншими Мт3 через використання мобілізаційних потужностей, тому цьому питанню і присвячена стаття.

Ступінь розробленості проблеми. В існуючих публікаціях [1] наведено досвід країн світу у створенні та організації виробництва OBT та Мт3 шляхом використання мобілізаційних спроможностей оборонного сектору національної економіки. На жаль зазначений досвід не знайшов широкого застосування у практиці мобілізаційної підготовки підприємств національної економіки України різних форм власності. У вітчизняних публікаціях $[2,3]$ за цим напрямом недостатньо інформації щодо понятійного апарату формування мобілізаційних спроможностей оборонного сектору національної економіки в умовах ринкових економічних стосунків.

Метою дослідження $є$ проведення аналізу понятійного апарату в нормативно-правових актів держави щодо формування мобілізаційних спроможностей оборонного сектору національної економіки для задоволення потреб військових формувань в ОВТ і Мт3 в особливий період.
Викладення основного матеріалу. На сьогодні наукове та методичне забезпечення мобілізаційної підготовки та мобілізації у державі здійснюється із значними недоліками. За роки незалежності не проведено жодного наукового дослідження щодо функціонування національної економіки в особливий період, визначення іiї спроможностей для задоволення потреб оборони держави 3 урахуванням розгортання додаткових потужностей або без них. Нині відсутня методологія розроблення довготермінових та річних програм мобілізаційної підготовки та досвід їх фінансування.

Незважаючи на гучні заяви, національна економіка не взмозі задовольняти потреби ЗС України, інших військових формувань як у засобах збройної боротьби (бойових літаках, кораблях, танках, артилерії, засобах розвідки та радіоелектронної боротьби, ракетах та боєприпасах), так і у продукції загального користування (автомобілях, інженерних машинах, спеціальному спорядженні, нафтопродуктах тощо). Проте зазначеному питанню не достатньо приділяється увага під час складання державних програм економічного і соціального розвитку країни.

Досвід переведення національної економіки на функціонування в умовах особливого періоду (згідно з розпорядженням Кабінету Міністрів України від 01.07.2015 № 674-р) підтвердив незадовільний стан справ у цій сфері. Жодне 3 підприємств галузей національної економіки навіть не приступало до виконання покладених мобілізаційних завдань (замовлень). Більшість мобілізаційних завдань сформовані ще за часів СРСР, без 
врахування того, що технології виробництва зброї застаріли, висококваліфікованих фахівців не вистачає, досвід виробництва оборонної продукції в мирний час недостатній.

Виявився надто тривалим процес уточнення (визначення) мобілізаційних завдань (замовлень) для задоволення потреб ЗС України, інших військових формувань в особливий період. Хоча скоротити строки уточнення мобілізаційних завдань можна було шляхом застосування механізму, передбаченого "Порядком управління національною економікою України в особливий період", затвердженого постановою Кабінету Міністрів України (КМ України) від 02.04.2009 № 306-03, через розроблення та вмілу організацію виконання воєнно-господарського плану держави. Наразі порядок розроблення воєнногосподарського плану не визначено. Як наслідок проект акта Кабінету Міністрів України про встановлення уточнених мобілізаційних завдань розроблявся понад три роки 3 моменту прийняття Урядом рішення про переведення національної економіки на функціонування в умовах особливого періоду.

Затримка 3 визначенням і доведенням до виконавців нових мобілізаційних завдань призводить до того, що надані до Міністерства економічного розвитку i торгівлі України потреби, внаслідок організаційно-штатних змін у ЗС України (формування нових органів військового управління, з'єднань та військових частин тощо), вже через кілька місяців втрачають свою актуальність.

Найпроблемнішим мобілізаційної підготовки та мобілізації оборонного сектору національної економіки, що потребує законодавчого врегулювання, $\epsilon$ питання функціонування фінансової системи держави в особливий період, без ефективної дії якої керівники галузей, підприємств, установ та закладів (далі підприємств) не взмозі організувати якісну роботу щодо забезпечення потреб оборони держави згідно з встановленими Урядом мобілізаційними завданнями (замовленнями).

Окрема проблема у питаннях функціонування фінансової системи держави в особливий період, це невизначеність в законодавстві порядку розроблення, наповнення та виконання Державного бюджету особливого періоду. Тільки при умові прийняття Верховною Радою України Державного бюджету України на відповідний бюджетний період Кабінет Міністрів України затверджує основні показники оборонного замовлення. Водночас відомо, що під час особливого періоду національна економіка працюватиме як у системі мобілізаційних завдань (замовлень), так і оборонних замовлень [4].

Відповідно до діючого законодавства, підготовка фінансової системи держави до функціонування в умовах особливого періоду належить до змісту мобілізаційної підготовки [5]. Проте Міністерство фінансів України систематично намагається переконати керівників центральних органів виконавчої влади про недоцільність розроблення законопроекту щодо функціонування фінансової системи в особливий період, оскільки це питання унормовано Бюджетним кодексом України. 3 такою позицією можна погодитися частково. Так, частиною другою статті 3 Бюджетного кодексу України визначено, що відповідно до Конституції України бюджетний період для Державного бюджету України за особливих обставин може бути інший, ніж передбачено частиною першою цієї статті. Особливими обставинами за яких Державний бюджет України може бути затверджений на інший період $\epsilon$ введення воєнного стану або оголошення надзвичайного стану. Тобто питання функціонування системи в умовах воєнного та надзвичайного стану дійсно унормовано зазначеним законом.

Проте у разі оголошення мобілізації та невведення воєнного або надзвичайного стану фінансова система функціонує як за умов мирного часу. Бюджетний період триває протягом календарного року ( 1 січня по 31 грудня). Видатки державного бюджету розподілені та здійснити їх оперативне коригування для забезпечення потреб оборони не можливо через тривалість бюджетного процесу.

Передбачений пунктом 22 прикінцевих та перехідних положень Бюджетного кодексу України механізм оперативного покриття потреб оборони є недосконалим 3 огляду на обсяги видатків, які передбачені. Пунктом 22 прикінцевих та перехідних положень передбачено надання права КМ України за погодженням 3 Верховним Головнокомандувачем 3С України приймати рішення щодо коригування бюджету (скорочення видатків i кредитування державного бюджету та їх спрямування до резервного фонду держбюджету для покриття потреб оборони) для використання додаткових вкрай необхідних ресурсів 3С України для відсічі збройної агресії, забезпечення недоторканості держкордону та захисту держави. 
Водночас статтею 48 Бюджетного кодексу встановлено, що розпорядники бюджетних коштів беруть бюджетні зобов'язання та здійснюють платежі тільки в межах бюджетних асигнувань, встановлених кошторисами, узятими на облік органами Казначейства України.

Кошторисами не передбачені видатки на фінансування мобілізаційних завдань (замовлень), що ставить під загрозу питання задоволення потреб ЗС України та інших військових формувань в особливий період.

Також частиною третьою статті 48 Бюджетного кодексу України зазначається, що розміщення замовлення, укладення договору, придбання товару, послуги тощо без відповідних бюджетних асигнувань $€$ недійсними.

На матеріально-технічне забезпечення військових формувань у мирний час та особливий період негативно впливають:

банкрутство, ліквідація підприємстввиконавців із мобілізаційними замовленнями;

неможливість укласти договори на виконання мобілізаційних завдань 3 окремими суб'єктами господарювання різних форм власності через незацікавленість бізнесу у їх реалізації - невизначеність обсягів і строків отримання прибутку, додаткові витрати на виконання заходів із мобілізаційної підготовки, які невідомо коли можуть бути покриті, додаткові перевірки контролюючих органів тощо;

незавершеність

імпортозаміщення;

процесу

проблеми зі створенням, накопиченням та зберіганням запасів сільськогосподарської продукції;

незабезпеченість підприємств-виконавців мобілізаційних завдань

(замовлень) матеріальними цінностями мобілізаційного резерву для розгортання виробництва, надання послуг;

труднощі, пов'язані із забезпеченням комплектуючими до зразків озброєнь, які виготовлені за часів СРСР; озброєнь;

відсутність серійного

виробництва

відсутність практики організації виробництва в мирний час у рамках державного оборонного замовлення продукції, яка передбачена для масштабного забезпечення потреб оборони в особливий період.

На сьогодні та протягом кількох років поспіль за довготерміновими програмами мобілізаційної підготовки фінансується лише утримання пунктів управління (запасних міських та позаміських) державних органів. Решта питань відповідно до змісту мобілізаційної підготовки фінансуванням не охоплені.

Фінансування створення, розвитку та утримання мобілізаційних потужностей 3 Державного бюджету роками не передбачається.

Нині відповідно до законодавства здійснюється бронювання військовозобов'язаних, що працюють на підприємствах, яким встановлені мобілізаційні завдання. Водночас певна кількість цих підприємств втратили спроможності (або не в змозі) виконувати такі завдання через перепрофілювання, банкрутство, санацію, зміну форми власності. Деякі мобілізаційні завдання втратили актуальність внаслідок змін потреби ЗС України. Як наслідок, війська (сили) в особливий період не отримають продукції, роботи, послуг, що очікуються.

Цілеспрямована підготовка керівного складу державних органів, органів місцевого самоврядування до дій у разі мобілізації на єдиній методологічній основі практично не здійснюється.

Перевірка та оцінка стану мобілізаційної готовності національної економіки, органів державної влади, інших державних органів, органів місцевого самоврядування до цього часу не здійснювалася через відсутність затвердженого порядку проведення такої перевірки. Урядом це питання врегульовано [6]. Проте затверджених показників критеріїв оцінки мобілізаційної готовності зазначених органів та підприємств до тепер немає.

Варто підкреслити, що розв'язання наведених проблем необхідно розпочати 3 розгляду Верховною Радою України проекту нової редакції Закону України "Про мобілізаційну підготовку та мобілізацію" i його прийняття. Згаданий законопроект передбачає кардинальні зміни засад функціонування системи мобілізаційної підготовки і проведення мобілізації, зокрема, в частині, що стосується національної економіки, іiі діяльності, спрямованої на задоволення потреб оборони держави. Впровадження Закону України потребує переопрацювання (розроблення нових) актів Президента України та КМ України, що регулюють питання у цій сфері.

Крім того, вважається за доцільне менше покладатися на можливості національної економіки щодо задоволення 
потреб оборони держави за рахунок мобілізаційних завдань в особливий період. Досвід мобілізаційної підготовки провідних країн світу показує, що потрібно сконцентрувати зусилля на завчасному i плановому створенні необхідних запасів у мирний час. Для цього необхідно формувати відповідні програми розвитку галузей національної економіки для створення необхідних технологій і продукції, здійснювати ïх накопичення 3 урахуванням потреб, життєвого циклу, строків зберігання i норм використання.

Висновок. Таким чином, переважна більшість проблемних питань щодо формування мобілізаційних спроможностей оборонного сектору національної економіки полягає у площині нормативно-правового, методичного i кадрового забезпечення. Більшість проблем у сфері мобілізаційної підготовки держави можна розв'язати шляхом формування та виконання довготермінових та річних програм мобілізаційної підготовки. До того ж вирішальним чинником успіху буде забезпечення гарантованого їх фінансування.

\section{СПИСОК ВИКОРИСТАНОЇ ЛІТЕРАТУРИ}

1. В. Яровой Розвиток оборонно-промислового комплексу Республіки Польщі під час іiі інтегрування в НАТО та Європейський союз.

2. В. А. Нікітін Реформування ОПК Оборонний вісник № 5 (2015), - К.: Центр воєнної політики та політики безпеки. 2015. - С. 10-3.

3. Методологічні аспекти оцінки мобілізаційних спроможностей національної економіки, науково-методичне видання. - Київ: Міністерство оборони України. - 198 с., посібник, інв. 16843/17.

4. Закон України "Про державне оборонне замовлення"

5. Закон України "Про мобілізаційну підготовку та мобілізацію”, частина третя, стаття 3

6. Постанова Кабінету Міністрів України від 11.10.2017 №796

Стаття надійшла до редакції 15.05.2018

Гриненко А. И., к.воен.н., доцент;

Кутовой О. П., К.Т.н., с.н.с.;

Шапталенко Н. И., к.Т.н., доцент

Центр военно-стратегических исследований Национального университета обороны Украины имени Ивана Черняховского, Киев

Современные проблемы мобилизационной подготовки и мобилизации оборонного сектора национальной экономики и пути их решения

Резюме. В статье обоснована необходимость совершенствования системы управления и организации планирования мобилизационной подготовки предприятий, организаций и учреждений оборонного сектора экономики определёнными способами для удовлетворения потребностей вооружённых сил. Предложен необходимый аппарат для решения определенных проблем.

Ключевые слова: вооружение; военная техника; мобилизационная подготовка и мобилизация; мобилизационные возможности; оборонный сектор национальной экономики.

\section{A. Grinenko, PhD (Military), assistant professor;}

O. Kutoviy, PhD (Technical), senior researcher;

N. Shaptalenko, PhD (Technical), assistant professor

Center for Military and Strategic Studies of the National Defence University of Ukraine named after Ivan Cherniakhovskyi, Kyiv

Modern problems of mobilizational preparation and mobilization of defensive sector of national economy that ways of their decision

Resume. The necessity of perfection of control system and organization of planning of mobilizational preparation of enterprises is reasonable in the article, organizations and establishments of defensive sector of economy by certain methods for satisfaction of necessities of military powers. A necessary vehicle is offered for the decision of certain problems.

Keywords: armament; military technique; mobilizational preparation and mobilization; mobilizational possibilities; defensive sector of national economy. 